\title{
The Retrieval and Analysis on Modern Apprenticeship Research
}

\author{
Yuanyuan Zeng, Haixiang $\mathrm{Hu}$ \\ School of Applied Sciences, Jiangxi University of Science and Technology, Ganzhou 341000 \\ China
}

Keywords: Modern apprenticeship, document retrieval, college-enterprise cooperation, working and learning alternation, dual system

\begin{abstract}
Modern apprenticeship is already the key point in vocational education in China and widely acclaimed. It is retrieved with the keyword "modern apprenticeship" in www.cnki.net (the biggest electronic platform of academic paper in China), it is found that modern apprenticeship has become the core of study, researchers put great efforts in college-enterprise cooperation, vocational education, dual system, working and learning alternation, and the number of study documents is rising. Furthermore, the researchers study on existing problems and solving methods in depth and focus on targeted solutions in theory and practice, which contributes much to the construction of the vocational education system in China.
\end{abstract}

\section{Introduction}

The Chinese State Council issued "the decision on accelerating the development of modern vocational education" in June 2014. This decision regarded modern apprenticeship as an important measure of cultivating talents and the national education strategy. Now modern apprenticeship has become the focus of vocational education and the research achievement is fruitful. This paper retrieves the www.cnki.net and analyzes the number and tendency of these documents, attempting to summarize and analyze heated research, pointing to the developed direction of research.

\section{The connotation of "modern apprenticeship" in China}

Compared with the traditional apprenticeship, it is found that traditional apprenticeship is also called wrap apprenticeship, which is a kind of skill inheritance achieved by working together in workshops between master and apprentice. This is a kind of skill acquisition in a highly situational environment. The characteristic is no systemic of theoretical study, insisting the combination of learning and working, learning and using. But modern apprenticeship is coming up from traditional apprenticeship, stressing development and innovation. Modern apprenticeship, which is governmentled and involved in industry association deeply, is a kind of talents training mode based on collegeenterprise cooperation. It insists on learning and using, producing and learning, learning with using, producing with learning, it emphasizes professional ability, and aims to cultivate technologic skills. It requires the systematic theoretic sturdy and the field practice. So modern apprenticeship is the dual system of talents training mode under legal protection based on combination of production and teaching, alternation of working and learning, education of dual system, binding of theory and practice.

\section{The research methods}

By retrieving with keywords nearly ten years, the retrieval platform was www.cnki.net(CNKI), including periodical library, domestic conference library, international conference library, newspaper, thesis library of doctor and master and so on. The release date was set as 2000.1.1-2017.4.3. By retrieving, it could be known the quantity of the documents. By calculating the publications each year, drawing the relevant graphs, it was researched about the content, focus and trend on relevant documents which were cited frequently. It is noted that the amount of documents is predictive value in Fig. 1, Fig. 3, Fig. 5 to Fig. 9 in 2017. 


\section{The results and analysis of retrieval documents}

\subsection{The retrieval and analysis of "modern apprenticeship"}

Based on the keyword of "modern apprenticeship", 1748 documents are searched all together. The publication of documents annually is shown in Fig. 1. The amount of documents is relatively few and rising slowly from 2010 to 2013, while the amount of documents increases rapidly after 2014, specifically, it reaches 114 in 2014, afterwards, the rising speed is much quicker. The amount of documents reaches 462 and 927 in 2015 and 2016. It will reach 983 in 2017. The changing time is relevant to official document on "the decision on accelerating the development of modern vocational education" which was issued in 2014. Therefore, the academic papers lay more emphasis on the research of modern apprenticeship. In 2015, the Ministry of Education issued 2 documents on "the suggestions of carrying out modern apprenticeship" and "the pilot work of carrying out modern apprenticeship", pushing and ensuring the pilot work of modern apprenticeship. It also gives rise to the number of the publications
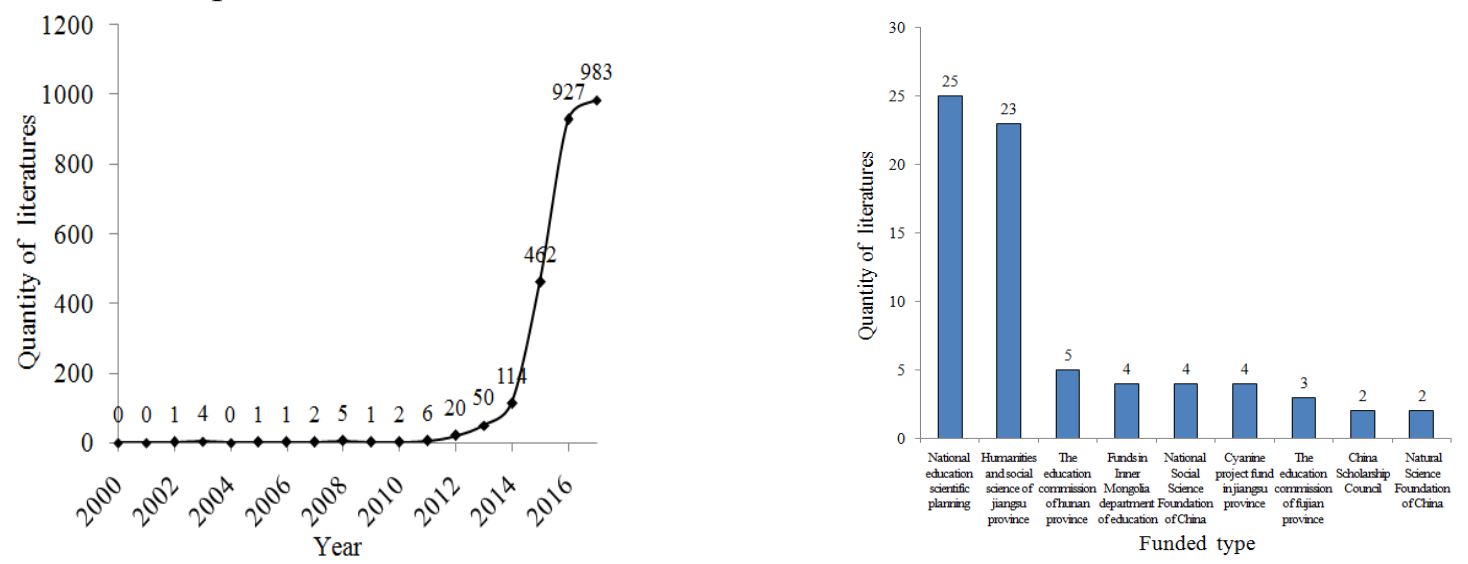

Fig. 1 The amount of documents from 2000-2017 Fig. 2 The numbers supported by various funds

It can be summarized about the funded type(in Fig. 2). It is clear that most documents haven't been supported by standard fund. In the documents that have been supported, 25 documents are supported by the National Education Plan(NEP), 23 documents are supported by Social Science of Education Department in Jiangsu Province, and the rest is relatively few. To be specific, the 25 documents which are supported by the NEP are cited frequently(in Tab. 1).

Tab. 1 The citations of 25 documents supported by the NEP

\begin{tabular}{|c|c|c|c|c|c|}
\hline $\begin{array}{c}\text { Total } \\
\text { Number }\end{array}$ & $\begin{array}{c}\text { Total } \\
\text { cites }\end{array}$ & $\begin{array}{c}\text { Download } \\
\text { total }\end{array}$ & $\begin{array}{c}\text { Average number of } \\
\text { references }\end{array}$ & $\begin{array}{c}\text { Average citations } \\
\text { per article }\end{array}$ & $\begin{array}{c}\text { Average number of } \\
\text { downloads }\end{array}$ \\
\hline 25 & 452 & 17750 & 3.08 & 18.08 & 710 \\
\hline
\end{tabular}

From Tab. 1, each one is quoted for 18.08 times, such as in 2011, Guan Jing's "The Features and Enlightenment of Western Modern Apprenticeship" has been cited for 157 times. The download times have reached 177750. The 6 documents frequently cited are shown in Tab. 2. From Tab. 2, the theme of these documents discusses the features and enlightenment of western modern apprenticeship, the construction and outlet of modern apprenticeship in vocational education and so on, which is consistent with the early stage of carrying out modern apprenticeship in our country.

By calculating the numbers which are funded by the NEP, It can be known that the numbers are increasing from fig. 3. It shows that the high-leveled fund focuses on the research of modern apprenticeship gradually. By calculating the numbers of other keywords, the keywords that rank top 3 are college-enterprise cooperation, personnel training mode and vocational education, the numbers are respectively $241,219,179$. The modern apprenticeship is a main fulcrum of vocational education. The college-enterprise cooperation is an important media of modern apprenticeship. Meanwhile, the modern apprenticeship is a new personnel training mode. Therefore, it coincides with the current research hotpot very well. Calculating the numbers of keyword on college-enterprise(in Fig. 5), it can be shown that the curve form is similar to Fig. 1. The reason is that the deeper college-enterprise is put forward definitely when the documents research the modern apprenticeship, which further attests that the college-enterprise is an important media of modern apprenticeship. From Tab. 3, the 
researching themes are mainly the problems and solutions to the modern apprenticeship, and concentrating more on the countermeasures in theory and practice.

Tab. 2 The most cited 6 documents supported by the NEP

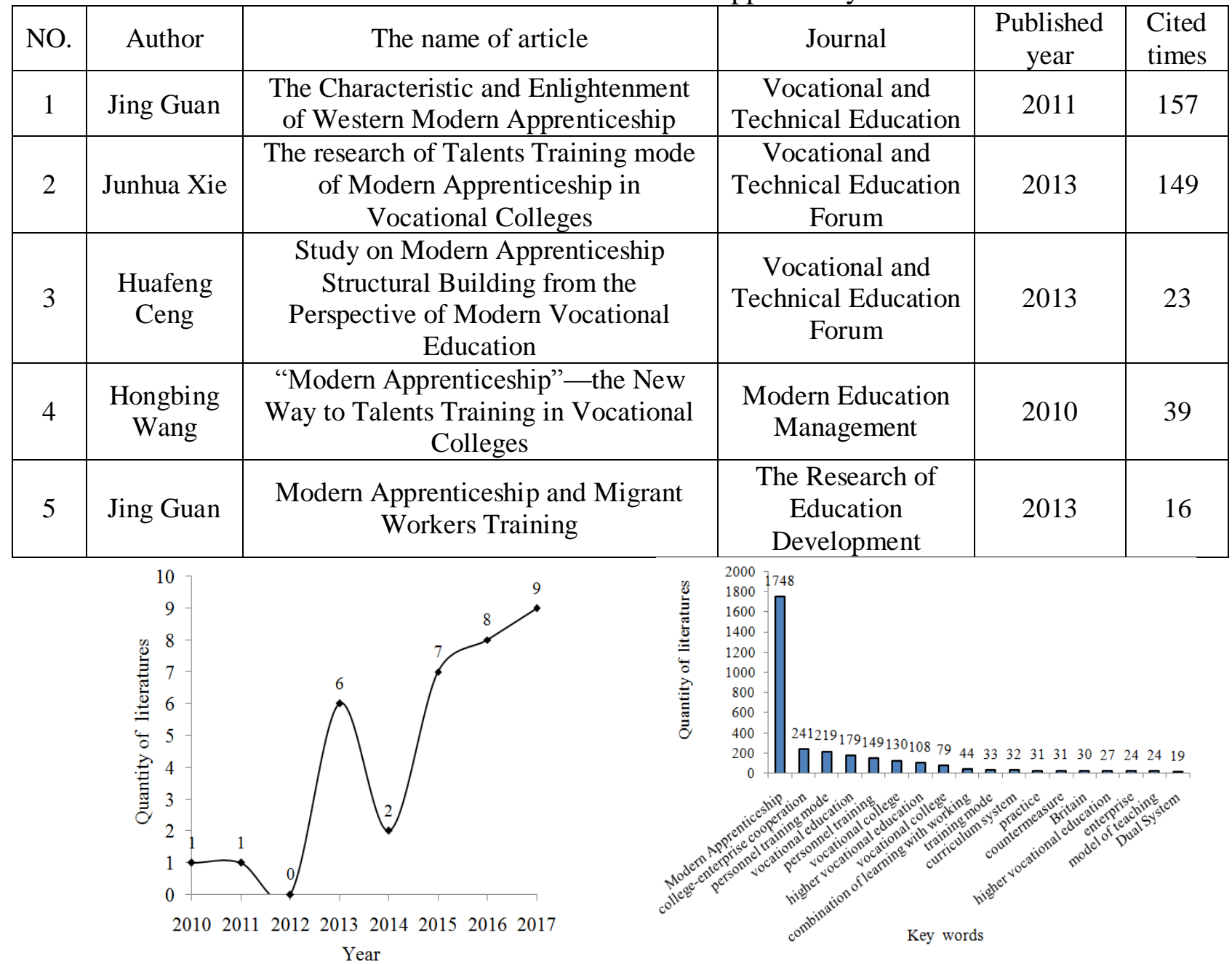

Fig. 3 The amount of documents funded by the NEP Fig. 4 the amount of other keywords

\subsection{The retrieval and analysis of "working and learning alternation"}

Based on the keyword of "working and learning alternation", it can be searched 743 documents, the amount of documents annually is shown in Fig. 6. The researching documents which focus on working and learning alternation appear largely from 2006, the first peak comes up in 2009. The amount is 109 which reaches the summit in 2013. Afterwards, the number is decreasing. It shows that working and learning alternation is a main fulcrum of vocational education and it attracts the academic circle's attention. After 2014, the academic circle focuses on the research of modern apprenticeship, accordingly, The amount of "working and learning alternation" is decreasing gradually. It also has been found that the researching hotpot is the construction of personnel training mode, the construction of curriculum system and the exploration of practice. 

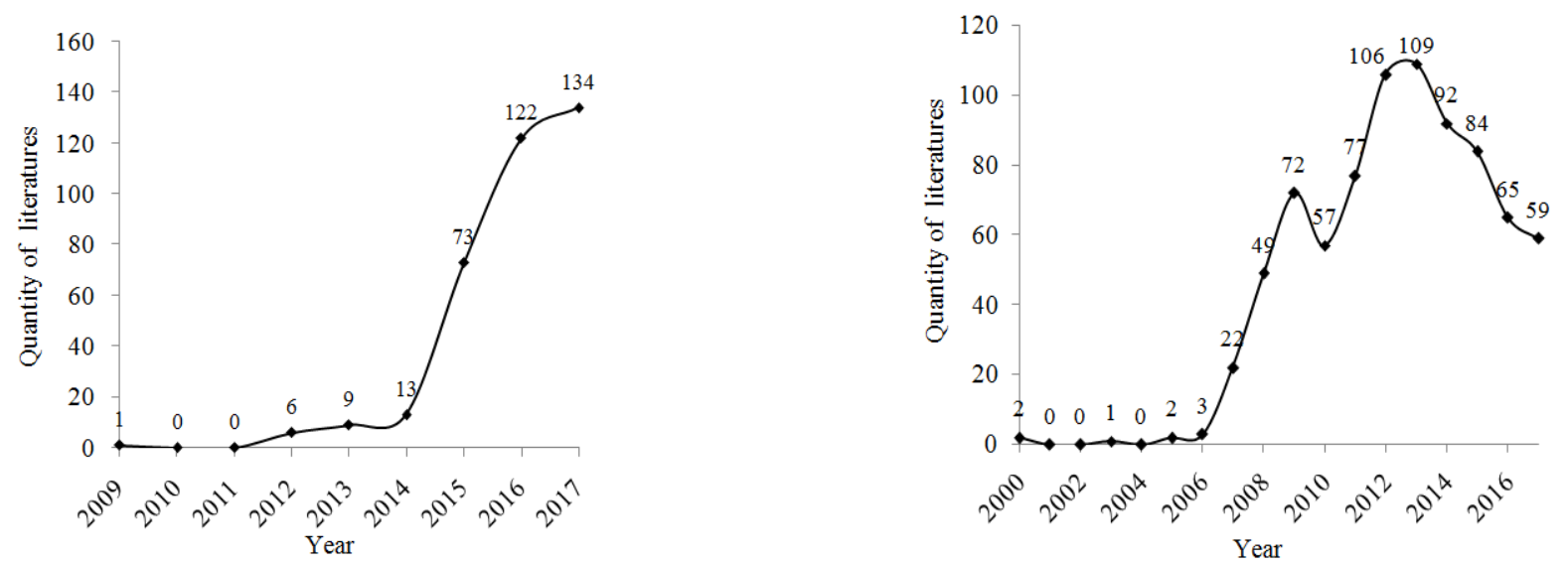

Fig. 5 The amount on "college-enterprise" Fig. 6 The amount on "working and learning alternation"

Tab. 3 the most cited 6 documents on "college-enterprise"

\begin{tabular}{|c|c|c|c|c|c|}
\hline NO. & Author & The name of article & Journal & $\begin{array}{c}\text { Published } \\
\text { year }\end{array}$ & $\begin{array}{c}\text { Cited } \\
\text { times }\end{array}$ \\
\hline 1 & $\begin{array}{c}\text { Pengfei } \\
\text { Zhao }\end{array}$ & $\begin{array}{c}\text { The Practice and Connotation Talents } \\
\text { Training mode of Modern } \\
\text { Apprenticeship }\end{array}$ & $\begin{array}{c}\text { Vocational and } \\
\text { Technical Education } \\
\text { in China }\end{array}$ & 2014 & 97 \\
\hline 2 & $\begin{array}{c}\text { Jianshe } \\
\text { Wu }\end{array}$ & $\begin{array}{c}\text { Five Difficult Problems to Modern } \\
\text { Apprenticeship Which Remains to Be } \\
\text { Solved in Higher Vocational } \\
\text { Education }\end{array}$ & $\begin{array}{c}\text { Research in Higher } \\
\text { Education }\end{array}$ & 2014 & 84 \\
\hline 3 & $\begin{array}{c}\text { Qifu } \\
\text { Zhang }\end{array}$ & $\begin{array}{c}\text { The Theory and Practice of Modern } \\
\text { Apprenticeship in Higher Vocational } \\
\text { Education }\end{array}$ & $\begin{array}{c}\text { Vocational and } \\
\text { Technical Education } \\
\text { Cai }\end{array}$ & $\begin{array}{c}\text { The Problems and Measures of } \\
\text { Modern Apprenticeship in Higher } \\
\text { Vocational Education }\end{array}$ & $\begin{array}{c}\text { Journal of Henan } \\
\text { Institute of Science } \\
\text { and Technology }\end{array}$ \\
\hline 5 & $\begin{array}{c}\text { Zhiqun } \\
\text { Zhao }\end{array}$ & $\begin{array}{c}\text { Modern Apprenticeship in Higher } \\
\text { Vocational Education of China- } \\
\text { History, Current situation Future } \\
\text { Technical Education } \\
\text { in China }\end{array}$ & 2012 & 2013 & 36 \\
\hline 6 & $\begin{array}{c}\text { Chuanwei } \\
\text { Li }\end{array}$ & $\begin{array}{c}\text { The Research and Practice on Talents } \\
\text { Training mode of Modern } \\
\text { Apprenticeship }\end{array}$ & $\begin{array}{c}\text { Vocational and } \\
\text { Technical Education } \\
\text { Forum }\end{array}$ & 2015 & 28 \\
\hline
\end{tabular}

\subsection{The retrieval and analysis of "college-enterprise cooperation}

It can be searched 18989 documents based on the keyword of "college-enterprise cooperation". The publication of documents annually is shown in Fig. 7. From Fig. 7, The amount is very large all the time from 2000 to 2017. In 2015, the number of documents is 2975 , which reaches the summit. It shows that the college-enterprise cooperation is a main fulcrum of vocational education and it attracts the academic circle's attention. After 2014, the chinese government strives to develop modern vocational education and come up with an idea of cultivating modern apprenticeship, the academic papers pay more attention to the modern apprenticeship. Therefore, the number of documents is rising annually. At present, it is expected that the amount of documents will increase, indicating that the academic circle will concentrate more on "college-enterprise cooperation". It also has been found that the researching hotpot of college-enterprise cooperation is the construction of cooperation mode, the problems and countermeasures, the exploration of practice.

\subsection{The retrieval and analysis of "dual system"}

It can be searched 3886 documents based on the keyword of "dual system". The publication of documents annually is shown in Fig. 8. From Fig. 8, the researching documents of dual system are focused on by people after 2000. it can be estimated that the number of documents will be 386 in 2017. Dual system is a main fulcrum of vocational education and it attracts the academic attention. Thus, the number of documents is increasing. At present, the amount of documents that is related to 
"dual system" will increase, indicating that the academic circle will concentrate more on the research of dual system. It also has been found that the researching hotpot of dual system is the training mode in working process, the curriculum system of dual system and the exploration of practice
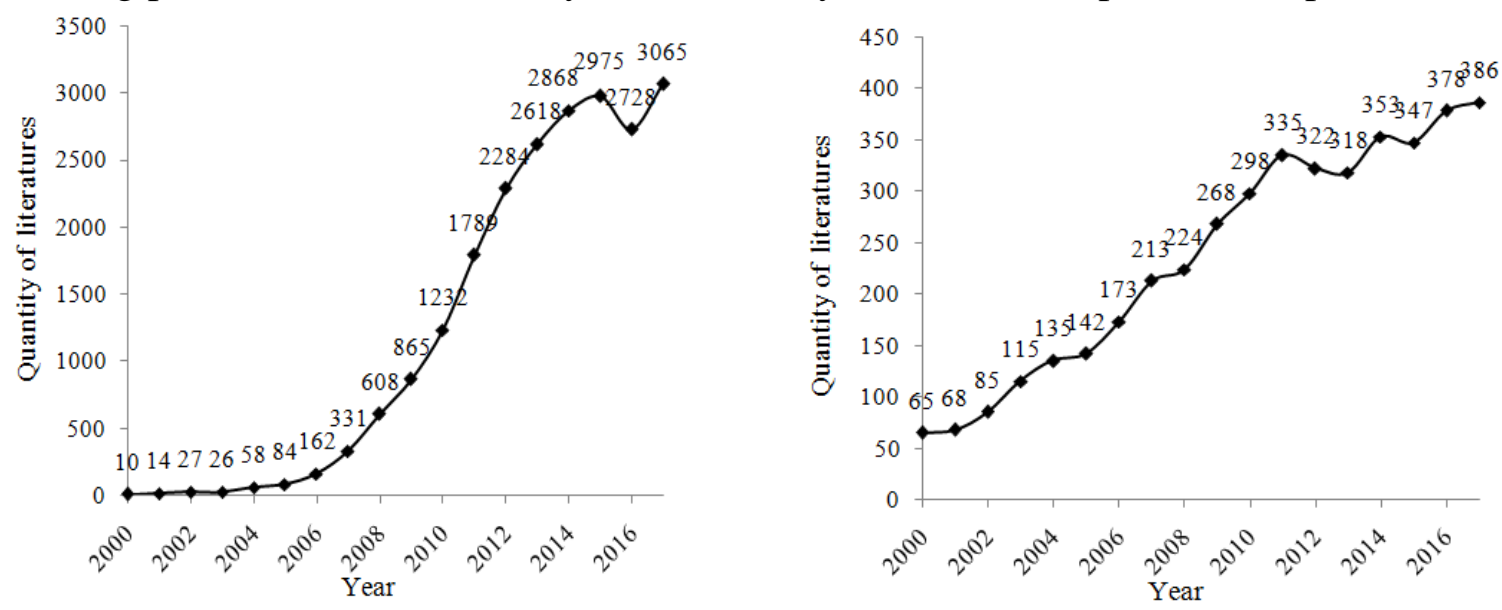

Fig. 7 The curve of "college-enterprise cooperation" Fig.8 The curve of "dual system" 4.5 The retrieval and analysis of "vocational education"

It can be searched 26260 documents based on the keyword of "vocational education". The publication of documents annually is shown in table Fig. 9. From Fig. 9, the researching documents of vocational education are focused on after 2000. In 2014, the chinese government strives to develop modern vocational education. The number of documents is 2657 in 2015, showing that the academic circle has laid more emphasis on modern vocational education. It is estimated that the amount of documents will be 2656 in 2017. At present, the amount of documents will increase predictably, indicating that the academic circle will concentrate more on the research of vocational education in the following years. It also has been found that the researching hotpot of vocational education is the major problems of vocational education, the curriculum system of vocational education and the countermeasures of college-enterprise cooperation.

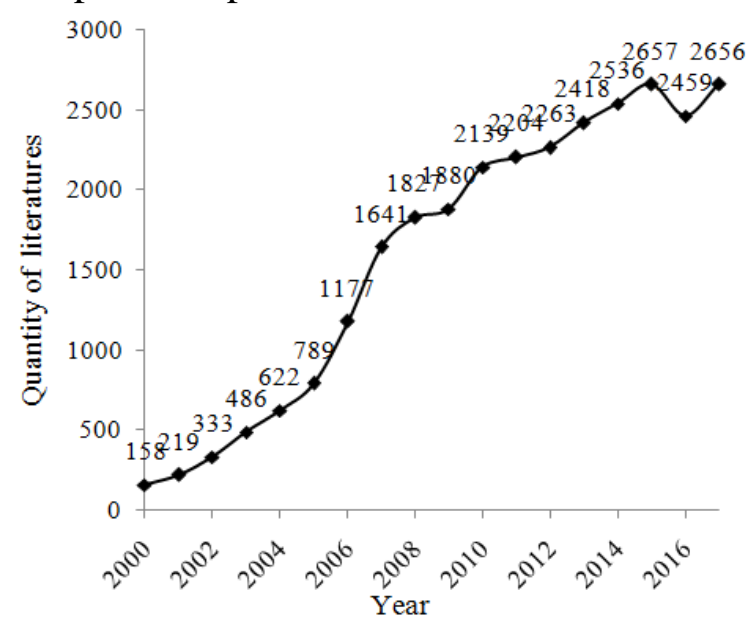

Fig. 9 The curve of "vocational education"

\section{Conclusion}

The modern apprenticeship is a personnel training mode based on college-enterprise cooperation aiming to educate people by teachers and enterprise master. The main fulcrum embodies collegeenterprise cooperation, the combination of production and education, the working and learning alternation, the dual system and other aspects. By researching documents of modern apprenticeship, summarizing the hotpot and trend, it can be grasped about the researching direction. In general, the modern apprenticeship has been the main fulcrum of vocational education and accepted by vocational education circle. But it should be aware that there is a far distance in vocational education level between china and western developed countries. In recent years, the academic circle research the 
college-enterprise cooperation, vocational education and dual system deeply. With the further exploration of vocational education, the vocational education system in our country will be improved absolutely

\section{Acknowledgments}

The paper is funded by the Youth Project of Humanities and Social Sciences by Ministry of Education, the research title is "A New Way of Professional Undergraduate Education: the Teaching Process Design and Empirical Research Based on Modern Apprenticeship"(Number: 15YJC880120); The paper is also funded by the Education Scientific Planning Project of Jiangxi Education Science(the Twelfth Five-Year Plan), the research title is "The Teaching Process Design and Demonstration Research of Modern Apprenticeship - Take a Modular Curriculum As an Example"(Number: 15ZD019).

\section{References}

[1]. Yuman Lv, Guoqing Xu. On the Factors affecting the initiative of the master in Modern Apprenticeship [J]. Vocational and Technical Education Forum, 2017, 33(4):35-38

[2]. Jing Li, Bin Cheng. On the Reform of Business Management Talents Training Mode of Modern Apprenticeship [J]. Modern Education Science, 2015, 32(9):54-58

[3]. Jing Guan, Weiping SHI. The Characteristic and Enlightenment of Western Modern Apprenticeship [J]. Vocational and Technical Education, 2011, 32(31):77-83

[4]. Huafeng Ceng. The Construction and Research of Modern Apprenticeship in Modern Vocational Education System [J]. Vocational and Technical Education Forum, 2013, 29(16):30-33

[5]. Hongbin Wang, Wanyu Lu. Modern Apprenticeship-The New Way to Talents Training in Vocational College [J]. Modern Education Management, 2010, 30(11):83-85

[6]. Jianshe Wu. Five Difficult Problems of Modern Apprenticeship Which Remains to Be Solved In Higher Education [J]. Higher Education Research, 2014, 35(7):41-45 